\title{
PENGARUH BUDAYA ORGANISASI, KOMITMEN ORGANISASI, DAN MOTIVASI KERJA TERHADAP KEPUASAN KERJA DAN KINERJA KARYAWAN
}

\author{
Zainul Arifin Noor \\ arifin_uvaya@gmail.com \\ Universitas Achmad Yani Banjarmasin, Kalimantan Selatan
}

\begin{abstract}
This research aims to test and prove the influence of organizational culture, organizational commitment, and motivation of work towards job satisfaction and performance of employees of PT Indofood Sukses Makmur Tbk Kalimantan. The population in this study were employees of PT Indofood Sukses Makmur Tbk Kalimantan some 392 employees originating from the manufacturing, human resources development, marketing, and accounting. Using the formula, the respondent elected slovin as samples of 50.5\% of the number of 198 employees originating from the manufacturing of 155 employees, human resources a number of 19 employees, marketing a number of 14 employees, and accounting of 10 employees. Based on the results of data analysis using Structural Equation Modeling (SEM) through AMOS 16.0, the results showed the 7 proposed hypotheses, there is a significant hypothesis 6 or received and there is a rejected hypothesis 1. As for the hypothesis is a hypothesis accepted: 1. Organizational culture affect significantly to job satisfaction of employees. Hypothesis 2. Organizational commitment affect significantly to job satisfaction of employees, the hypothesis 3. Influential work motivation significantly to job satisfaction of employees, hypothesis 4. Organizational culture affect significantly the performance of employees, the hypothesis 6. Significant impact on the motivation of working performance of employees, and hypotheses 7. Job satisfaction influence significantly the performance of the employees of PT Indofood Sukses Makmur Tbk Kalimantan. The hypothesis was rejected while the 1 is the hypothesis that 5 has no effect on the Organization's commitment to the performance of the employees of PT Indofood Sukses Makmur Tbk Kalimantan
\end{abstract}

Key words: Organizational Culture, Organizational Commitment, Motivation of work, Job Satisfaction, and Job Performance of Employees

\begin{abstract}
ABSTRAK
Penelitian ini bertujuan untuk menguji dan membuktikan pengaruh budaya organisasi, komitmen organisasi, dan motivasi kerja terhadap kepuasan kerja dan kinerja karyawan PT Indofood Sukses Makmur Tbk Kalimantan. Populasi dalam penelitian ini adalah karyawan PT Indofood Sukses Makmur Tbk Kalimantan beberapa 392 karyawan yang berasal dari manufaktur, pengembangan sumber daya manusia, pemasaran, dan akuntansi. Menggunakan rumus, responden terpilih Slovin sebagai sampel dari 50,5\% dari jumlah 198 karyawan yang berasal dari pembuatan 155 karyawan, sumber daya manusia sejumlah 19 karyawan, pemasaran sejumlah 14 karyawan, dan akuntansi dari 10 karyawan. Berdasarkan hasil analisis data menggunakan Structural Equation Modeling (SEM) melalui program AMOS 16.0, hasil penelitian menunjukkan hipotesis yang diajukan 7, ada hipotesis yang signifikan 6 atau diterima dan ada hipotesis ditolak 1. Adapun hipotesis merupakan hipotesis diterima: 1. Budaya organisasi berpengaruh signifikan terhadap kepuasan kerja karyawan. Hipotesis 2. Komitmen organisasi berpengaruh signifikan terhadap kepuasan kerja karyawan, hipotesis 3 . Berpengaruh motivasi kerja secara signifikan terhadap kepuasan kerja karyawan, hipotesis 4 . Budaya organisasi berpengaruh signifikan terhadap kinerja karyawan, hipotesis 6. Dampak yang signifikan terhadap motivasi kinerja kerja karyawan, dan hipotesis 7. Pengaruh Kepuasan kerja secara signifikan kinerja karyawan PT Indofood Sukses Makmur Tbk Kalimantan. Hipotesis ditolak sedangkan 1
\end{abstract}


adalah hipotesis bahwa 5 tidak berpengaruh pada komitmen organisasi terhadap kinerja karyawan PT Indofood Sukses Makmur Tbk Kalimantan.

Kata kunci: Budaya Organisasi, Komitmen Organisasi, Motivasi kerja, Kepuasan Kerja, dan Prestasi Kerja karyawan

\section{PENDAHULUAN}

Dewasa ini persaingan dalam dunia usaha menunjukkan adanya persaingan yang semakin lama semakin ketat. Hal ini menuntut setiap perusahaan harus mampu menyediakan barang-barang atau jasa-jasa kepada konsumen dalam kualitas yang baik dan pelayanan yang baik pula. Mampunya perusahaan dalam menghadapi persaingan yang semakin ketat tersebut, tidak terlepas dari kemampuan atau kualitas yang ada pada sumber daya manusia atau karyawan di perusahaan tersebut. Tuntutan akan kemampuan dan tanggung jawab pada setiap pribadi yang ada di setiap perusahaan menjadi semakin tinggi. Selain kualitas sumberdaya yang menentukan, budaya organisasipun juga punya pengaruh dalam menghadapi persaingan yang semakin ketat.

Luthans (2005) mengungkapkan, budaya organisasi merupakan pola asumsi dasar yang diciptakan atau dikembangkan oleh kelompok tertentu saat mereka menyesuaikan diri dengan masalah-masalah eksternal dan integrasi internal yang telah bekerja cukup baik serta dianggap berharga, dan karena itu diajarkan pada anggota baru sebagai cara yang benar untuk menyadari, berpikir, dan merasakan hubungan dengan masalah tersebut. Hal ini pun tidak terlepas dari keberadaan perusahaan itu sendiri, dengan kata lain budaya organisasi yang dijalin dalam suatu perusahaan akan memberi dampak kepada kepuasan kerja karyawan yang pada akhirnya akan memberi peningkatan kinerja karyawan yang bersangkutan.

Pada saat perusahaan tumbuh dan menambahnya dengan sistem formal, para pimpinan harus dapat menjamin bahwa seluruh sistem yang ada akan memperkuat nilai-nilai budaya, walaupun organisasi selalu berubah (melalui karyawan baru dan promosi yang dilakukan), namun inti budaya akan selalu hidup. Dengan cara ini, kebijakan yang diberikan pimpinan dalam budaya organisasi, komitmen organisasi, dan motivasi kerja serta kepuasan kerja akan meningkatkan kinerja karyawan perusahaan dalam jangka panjang.

Pada perusahaan PT Indofood Sukses Makmur, Tbk. yang berdomisili di Kalimantan, kebijakan manajemen memiliki pengaruh yang lebih besar, karena pada perusahaan PT Indofood Sukses Makmur, Tbk ini pendiri adalah pemilik perusahaan sekaligus bertindak secara langsung menjadi pimpinan perusahaan atau berada dalam tingkatan dewan direksi atau manajemen puncak. Nilai dan norma-norma yang dimiliki manajemen puncak sekaligus pemilik dan pendiri perusahaan, melalui suatu gaya kepemimpinan atau kebijakan tertentu yang diberikan pimpinan sekaligus pemilik akan tertanam di dalamnya, dan berpengaruh terhadap budaya organisasi, komitmen organisasi, motivasi kerja yang ada di perusahan, dan akan memberi dampak kepada kepuasan kerja yang pada akhir nya akan mempengaruhi kinerja karyawan di PT Indofood Sukses Makmur, Tbk tersebut secara keseluruhan.

Bemardin dan Russel (dalam Mangkunegara:2006) menerangkan bahwa performance atau kinerja adalah catatan tentang hasil-hasil yang diperoleh dari fungsi-fungsi pekerjaan tertentu atau kegiatan tertentu selama kurun waktu tertentu. Kinerja menekankan pengertian sebagai hasil atau apa yang keluar (outcomes) dari sebuah pekerja an dan kontribusi mereka pada organisasi. Nawawi (2003) memberi pengertian tentang kinerja sebagai "suatu kegiatan peningkatan kualitas atau mutu kerja dari seorang pegawai yang nantinya ikut menentukan 
penilaian atas suatu jabatan terhadap seorang personil".

Budaya organisasi dan komitmen organisasi merupakan faktor yang paling kritis di dalam organisasi. Keduanya menentukan nada untuk seluruh organisasi dan mempengaruhi komunikasi, pengambilan keputusan, dan pola kepemimpinan dari seluruh sistem. Kedua hal ini penting karena suatu organisasi dibangun oleh individu-individu, di mana setiap anggota memiliki nilai-nilai, kepercayaan, dan motivasi sendiri-sendiri. Efektivitas organisasi dapat ditingkatkan dengan menciptakan budaya organisasi dan komitmen organisasi yang akan mencapai tujuan-tujuan organisasi dan pada saat yang sama akan memuaskan kebutuhan konsumen.

Kinerja merupakan sesuatu yang kompleks dan senantiasa perlu ditingkatkan baik dari sisi individual, kelompok, maupun organisasi. Hal ini dikarenakan kinerja merupakan tantangan yang harus dihadapi oleh semua komponen serta unsur organisasi dan merupakan urusan semua orang dalam organisasi, sehingga mereka mampu mengatasi situasi perekonomian dan moneter di Indonesia. Aksioma ini berlaku pada organisasi yang bergerak di berbagai bidang organisasi, seperti kenegaraan, politik, nirlaba, bisnis, sosial budaya, lembaga sosial masyarakat dan keagamaan.

Festinger dalam Kluvers dan Tippet (2009) mengemukakan, apabila seorang karyawan memiliki motivasi yang tinggi, namun yang dicapai tidak sesuai dengan harapan, maka karyawan tersebut secara sukarela akan membenahi aktivitasnya untuk mencapai apa yang diharapkan, begitu pula sebaliknya apabila seorang karyawan memiliki motivasi rendah, namun yang dicapai tidak sesuai dengan yang diharapkan, maka karyawan tersebut beranggapan bahwa itulah kemampuan yang dia miliki. Dengan teori yang diungkap Festinger tersebut, terlihat bahwa jika seorang karyawan memi liki motivasi yang tinggi, maka kinerja yang dicapai akan semakin tinggi pula.
Begitu pula untuk tingkat kepuasan, tingkat kepuasan seorang karyawan dipengaruhi oleh beberapa hal, baik kondisi yang berasal dari perusahaan, maupun berasal dari diri karyawan tersebut. Hal yang berasal dari organisasi/perusahaan di antaranya adalah budaya organisasi yang selalu melekat pada setiap perusahaan. Sedangkan hal-hal yang berasal dari diri karyawan di antaranya adalah komitmen yang diberikan karyawan terhadap perusahaan dan motivasi yang ada pada diri karyawan.

Berdasarkan pentingnya kinerja karyawan yang ada di PT Indofood Sukses Makmur Tbk., maka pengembangan yang dilakukan terhadap penelitian ini adalah mengacu pada fenomena yang ada di PT Indofood Sukses Makmur Tbk yang didalamnya budaya organisasi, komitmen organisasi, dan motivasi kerja karyawan akan mempengaruhi kepuasan kerja karyawan yang bersangkutan. Kepuasan kerja karyawan tersebut akan memberi dampak kepada kinerja karyawan yang ada, sehingga dengan dasar inilah topik penelitian ini disusun.

Berdasarkan latar belakang dan identifi kasi masalah yang telah dikemukakan, maka penelitian ini dapat dirumuskan sebagai berikut:

1 Apakah Budaya Organisasi berpengaruh signifikan terhadap Kepuasan Kerja Karyawan PT Indofood Sukses Makmur Tbk di Kalimantan?

2 Apakah Komitmen Organisasi berpengaruh signifikan terhadap Kepuasan Kerja Karyawan PT Indofood Sukses Makmur Tbk di Kalimantan?

3 Apakah Motivasi Kerja berpengaruh signi fikan terhadap Kepuasan Kerja Karyawan PT Indofood Sukses Makmur Tbk di Kalimantan?

4 Apakah Budaya Organisasi berpengaruh signifikan terhadap Kinerja Karyawan PT Indofood Sukses Makmur Tbk di Kalimantan?

5 Apakah Komitmen Organisasi berpengaruh signifikan terhadap Kinerja 
Karyawan PT Indofood Sukses Makmur Tbk di Kalimantan?

6 Apakah Motivasi Kerja berpengaruh signifikan terhadap Kinerja Karyawan PT Indofood Sukses Makmur Tbk di Kalimantan?

7 Apakah Kepuasan Kerja berpengaruh signifikan terhadap Kinerja Karyawan PT Indofood Sukses Makmur Tbk di Kalimantan?

\section{TINJAUAN TEORETIS}

\section{Tinjauan Pustaka dan Hipotesis}

Budaya organisasi sebagai perangkat sistem nilai-nilai (values), keyakinan-keya kinan (beliefs) atau norma-norma yang telah lama berlaku, disepakati dan diikuti oleh para anggota suatu organisasi sebagai pedoman perilaku dan pemecahan masalahmasalah organisasi. Menurut Kreitner dan Angelo (2003) mengemukakan budaya organisasi merupakan bagian nilai-nilai dan kepercayaan yang mendasari/menjadi identitas perusahaan/organisasi. Robbins dan Judge (2008) menyatakan bahwa budaya adalah sistem makna dan keyakinan bersama yang dianut oleh para anggota organisasi yang menentukan, sebagian besar cara mereka bertindak satu terhadap yang lain dan terhadap orang luar.

Luthans (2005) mengemukakan bahwa komitmen organisasi merupakan sikap yang didefinisi sebagai keinginan kuat untuk tetap sebagai anggota organisasi tertentu, keinginan untuk berusaha keras sesuai keinginan organisasi, keyakinan tertentu dan penerimaan nilai dan tujuan organisasi. Dengan kata lain bahwa komitmen merupakan sikap yang merefleksi loyalitas karyawan pada organisasi dan proses berkelanjutan, dimana anggota organisasi mengekspresikan perhatiannya terhadap organisasi dan keberhasilan serta kemajuan yang berkelanjutan. Tobing dalam Pantja Djati (2003) mengemukakan bahwa komitmen organisasi adalah tingkat kepercayaan dan penerimaan tenaga kerja terhadap tujuan organisasi dan mempunyai keinginan untuk tetap ada di dalam organi- sasi tersebut. Komitmen organisasi juga didefinisi sebagai suatu keadaan di dalam mana seorang karyawan memihak pada organisasi dan tujuan organisasi serta bersedia untuk menjaga keanggotaan dalam organisasi (Robbins, 2003).

Luthans (2005) mengemukakan bahwa komitmen organisasi bersifat multidimensi, maka terdapat perkembangan dukungan untuk 3 (tiga) model komponen yang diajukan oleh Meyer dan Allen, yaitu:

1. Komitmen afektif (affective commitment), yaitu keterkaitan emosional karyawan, identifikasi, dan keterlibatan dalam organisasi.

2. Komitmen kelanjutan (continuance commitment), yaitu komitmen berdasar kerugian yang berhubungan dengan keluarnya karyawan dari organisasi. Hal ini mungkin karena kehilangan senioritas atas promosi atau benefit.

3. Komitmen normatif (normative commitment), yaitu perasaan wajib untuk tetap berada dalam organisasi karena memang harus begitu. Tindakan tersebut merupakan hal benar yang harus dilakukan.

Wexley dan Gary (1992) mengemukan, motivasi adalah proses di mana perilaku diberikan energi dan diarahkan. Dalam motivasi terdapat unsur adanya arah yang dicapai dan adanya energi sebagai pendorong individu dalam mencapai sasaran tersebut. Istilah motivasi menurut Toha (1993) dapat juga diartikan dengan kebutuhan (need), keinginan (want), dorongan (drive) atau impuls. Motivasi merupakan unsur yang menentukan perilaku seseorang. Selain itu Gitosudarmo dan Sudita (2002) menyatakan bahwa motivasi adalah faktor-faktor yang ada dalam diri seseorang yang menggerakkan dan mengarahkan peri lakunya untuk memenuhi tujuan tertentu. Salah satu teori motivasi adalah teori kebutuhan akan prestasi yang diajukan oleh McClelland, di mana kebutuhan dibagi atas tiga jenis, yaitu kebutuhan akan prestasi (need for achievement), kebutuhan akan 
afiliasi (need for affiliation), dan kebutuhan akan kekuasaan (need for power)

Suprayitno (2006) menjelaskan bahwa umumnya seseorang mengejar pendidikan, kemampuan dan berusaha untuk selalu meningkatkan keahlian dan keterampilan bekerja yang baik dengan tujuan apabila bekerja dapat memperoleh kepuasan kerja. Khusus dalam perusahaan industri, kepuasan kerja menjadi dambaan utama, karena banyak menghabiskan waktu hidupnya dalam perusahaan atau tempat kerja yang mereka pilih. dilihat dari perspektif perusahaan, sejumlah riset telah membuktikan bahwa para karyawan yang lebih tinggi kepuasan kerjanya juga lebih tinggi kinerja yang dihasilkan. (Robbins, 2003) mengemukakan bahwa apabila angka kepuasan kerja karyawan meningkat, maka tingkat kemangkiran dan turn over karyawan dapat ditekan. Sejumlah riset membuktikan bahwa jika karyawan lebih puas dalam pekerja an mereka akan berdampak positif terhadap kesehatan fisik dan mental.

Robbins (2003) mengemukakan bahwa kepuasan kerja adalah sebagai suatu sikap umum seorang individu terhadap pekerjaan nya. Pekerjaan menuntut interaksi dengan rekan sekerja dan atasan, mengikuti aturan dan kebijakan organisasi, memenuhi standar kinerja, hidup pada kondisi kerja yang sering kurang ideal, dan hal serupa lainnya. Ini berarti penilaian (assesment) seorang karyawan terhadap puas atau tidak puasnya dia terhadap pekerjaan merupakan penjumlahan yang rumit dari sejumlah unsur pekerjaan yang diskrit (terbedakan dan terpisahkan satu sama lain). Dalam beberapa teori maupun kenyataan, terungkap bahwa kepuasan kerja akan berpengaruh secara signifikan terhadap kinerja karyawan.

Bemardin dan Russel (dalam Ruky: 2002) mendefinisi performance adalah catatan tentang hasil-hasil yang diperoleh dari fungsi-fungsi pekerjaan tertentu atau kegiatan tertentu selama kurun waktu tertentu. Kinerja menekankan pengertian sebagai hasil atau apa yang keluar (outcomes) dari sebuah pekerjaan dan kontribusi mereka pada organisasi.

Berdasarkan pada pembahasan terdahu lu, maka bisa diungkap bahwa ada keterkaitan antara budaya organisasi, komitmen organisasi, motivasi kerja, dan kepuasan kerja dengan kinerja karyawan. Keterkaitan ini tertuang dalam rerangka konseptual pada gambar 1.

Berdasarkan rerangka konseptual tersebut, maka hipotesis yang diajukan adalah: $\mathrm{H}_{1}$ : Budaya Organisasi berpengaruh signifikan terhadap Kepuasan Kerja Karyawan PT Indofood Sukses Makmur Tbk di Kalimantan.

$\mathrm{H}_{2}$ : Komitmen Organisasi berpengaruh signifikan terhadap Kepuasan Kerja Karyawan PT Indofood Sukses Makmur Tbk di Kalimantan.

$\mathrm{H}_{3}$ : Motivasi Kerja berpengaruh signifikan terhadap Kepuasan Kerja Karyawan PT Indofood Sukses Makmur Tbk di Kalimantan.

$\mathrm{H}_{4}$ : Budaya Organisasi berpengaruh signifikan terhadap Kinerja Karyawan PT Indofood Sukses Makmur Tbk di Kalimantan.

$\mathrm{H}_{5}$ : Komitmen Organisasi berpengaruh signifikan terhadap Kinerja Karyawan PT Indofood Sukses Makmur Tbk di Kalimantan.

$\mathrm{H}_{6}$ : Motivasi Kerja berpengaruh signifikan terhadap Kinerja Karyawan PT Indofood Sukses Makmur Tbk di Kalimantan.

$\mathrm{H}_{7}$ : Kepuasan Kerja berpengaruh signifikan terhadap Kinerja Karyawan PT Indofood Sukses Makmur Tbk di Kalimantan. 
H5

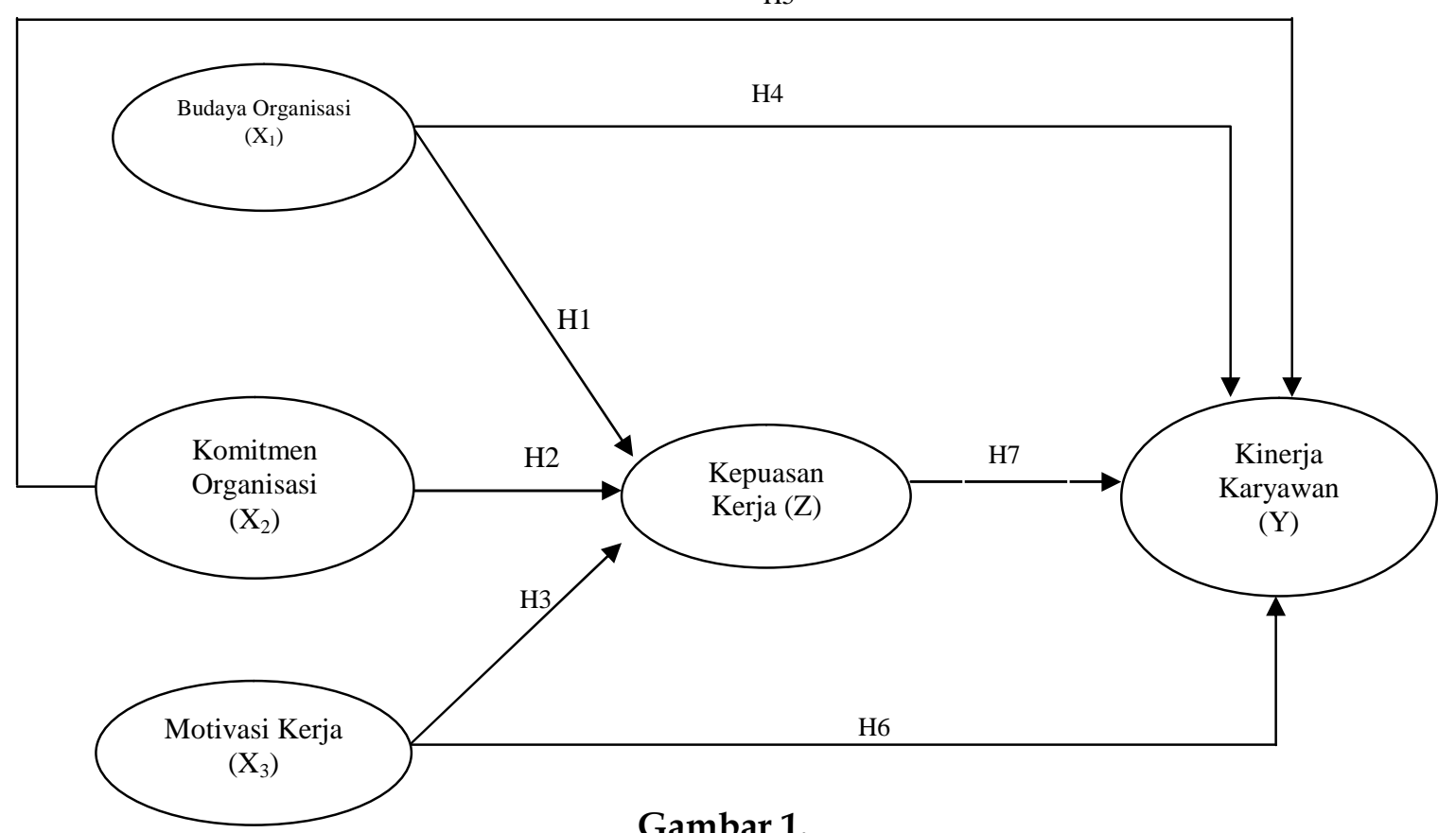

Gambar 1.

Sumber : Olahan Penulis

Rerangka Konseptual

\section{METODE PENELITIAN}

Penelitian ini menjelaskan hubungan kausal antara variabel Budaya Organisasi, Komitmen Organisasi, dan Motivasi Kerja dengan Kepuasan Kerja dan Kinerja Karyawan PT Indofood Sukses Makmur Tbk di Kalimantan. Populasi dalam penelitian ini, adalah seluruh karyawan PT Indofood Sukses Makmur Tbk di Kalimantan yang berada di tingkatan manajemen menengah kebawah atau kepala bagian ke bawah yang telah bekerja lebih dari 1 tahun. Karyawan yang memiliki kriteria tersebut sebanyak 392 orang, dengan perincian Departemen Manufacturing 306 orang, Human Resources Development 39 orang, Marketing 28 orang, dan Accounting 19 orang. Teknik penarikan sampel dilakukan dengan menggunakan metode proportional random sampling (teknik sampel proporsional). dengan menggunakan rumus yang dikemukakan oleh Slovin yaitu:

$n=\frac{N}{1+N \cdot e^{2}}$, dengan:

$n=\frac{392}{1+\left(392 x(0,05)^{2}\right)}=197,98 \approx 198$ responden
Dengan menggunakan perhitungan tersebut, maka jumlah responden sebesar 198 orang didistribusikan ke masing-masing departemen sebagai berikut: Manufacturing 155 orang, Human Resources Development 19 orang, Marketing 14 orang, dan Accounting 10 orang.

\section{Hasil Penelitian}

Untuk memastikan bahwa kuesioner yang disebar dapat diolah lebih lanjut, maka dilakukan uji validitas yang bertujuan untuk mengetahui sejauh mana kuesioner dapat mengukur apa yang diinginkan, dan uji reliabilitas untuk mengetahui keandalan (konsistensi) instrumen (alat ukur) berupa kuesioner. Hasil pengujian validitas untuk masing-masing item pertanyaan pada setiap variabel penelitian, yang meliputi variabel budaya organisasi, komitmen organisasi, motivasi kerja, kepuasan kerja dan kinerja karyawan diketahui bahwa korelasi product momment pearson untuk setiap indikator memiliki nilai signifikansi kurang dari 5\%, sehingga dapat disimpulkan bahwa semua indikator yang membentuk variabel budaya 
organisasi, komitmen organisasi, motivasi kerja, kepuasan kerja dan kinerja karyawan adalah valid. Dan hasil uji reliabilitas ini dilakukan dengan menggunakan teknik Cronbach's Alpha, hasil menunjukkan untuk semua variabel penelitian memiliki nilai lebih besar dari 0,60, sehingga dapat disimpulkan kuesioner pada masing-masing variabel penelitian dapat dinyatakan reliabel dan dapat dipercaya sebagi alat ukur yang menghasilkan jawaban yang konsisten

Penilaian responden atas masingmasing variabel penelitian dapat dijelaskan dengan melihat hasil pengolahan statistika deskriptif yang menunjukkan bahwa nilai mean (rata-rata) variabel budaya organisasi sebesar 4,26, variabel komitmen organisasi sebesar 4,23, variabel motivasi kerja sebesar 4,31, kepuasan kerja sebesar 4,27, dan variabel kinerja karyawan sebesar 4,28, maka dapat disimpulkan bahwa secara ratarata responden yang dijadikan sampel penelitian memiliki nilai yang tinggi.

\section{Analisis Model Pengukuran (Measurement Model Analysis)}

Merupakan suatu proses dari uji CFA yaitu confiratory factor analysis. berfungsi untuk mengidentifikasi apakah indikator merupakan konstrak dari variabel penelitian atau dengan kata lain indikator-indikator tersebut merupakan satu kesatuan atau memiliki undimensionalitas. Uji CFA dilakukan pada masing-masing variabel. Uji CFA dibagi menjadi dua yaitu pada variabel eksogen dan variabel endogen.

\section{Confirmatory Factor Analisis Variabel Eksogen}

Hasil uji CFA pada konstrak eksogen, yang terdiri dari variabel budaya organisasi, komitmen organisasi, dan motivasi kerja setelah direvisi yaitu menghilangkan indikator yang memiliki nilai loading factor kurang dari 0,5 yaitu indikator $\mathrm{X}_{1.4}$, sehingga gambarnya adalah sebagai berikut:

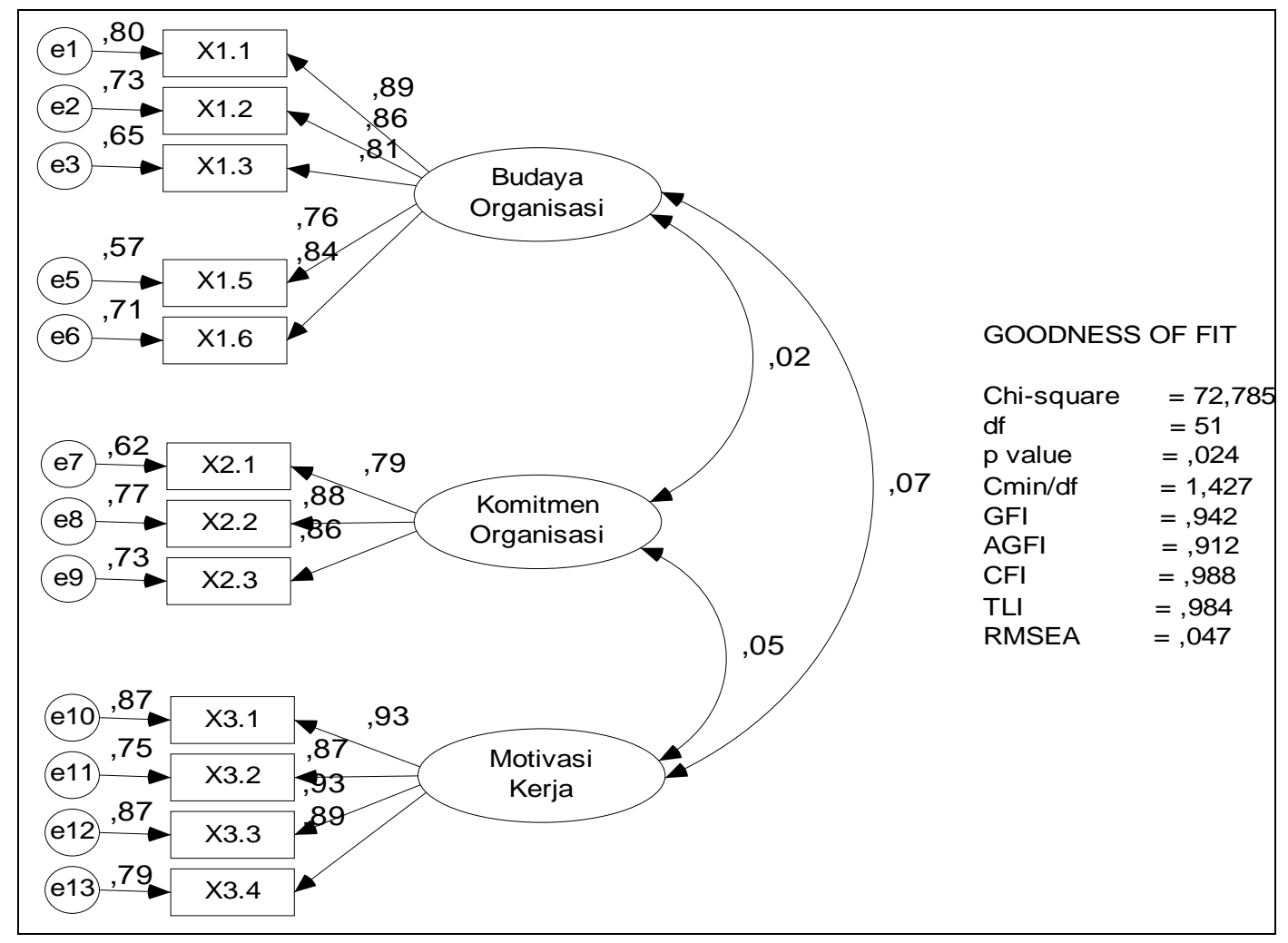

Gambar 2

Confirmatory Factor Analisis Variabel Endogen

Sumber : Hasil olahan Peneliti dengan Amos Ver. 16.0 
Untuk memastikan indikator tersebut telah memenuhi syarat tersebut dapat dilihat pada tabel 1.

Tabel 1.

Hasil Uji Validitas Kontrak Eksogen

\begin{tabular}{lllcccc}
\hline \hline & & \multicolumn{1}{c}{ Konstrak } & Estimate & S.E. & C.R. & P \\
\hline X1.1 & $<---$ & Budaya_Organisasi & 1 & & & \\
X1.2 & $<---$ & Budaya_Organisasi & 0,988 & 0,060 & 16,439 & 0,000 \\
X1.3 <--- & Budaya_Organisasi & 0,959 & 0,065 & 14,755 & 0,000 \\
X1.5 <--- & Budaya_Organisasi & 0,930 & 0,070 & 13,238 & 0,000 \\
X1.6 <--- & Budaya_Organisasi & 1,021 & 0,064 & 15,984 & 0,000 \\
X2.1 $<---$ & Komitmen_Organisasi & 1 & & & \\
X2.2 & $<---$ & Komitmen_Organisasi & 1,087 & 0,087 & 12,559 & 0,000 \\
X2.3 <--- & Komitmen_Organisasi & 0,992 & 0,080 & 12,434 & 0,000 \\
X3.1 $<---$ & Motivasi_Kerja & 1 & & & \\
X3.2 $<---$ & Motivasi_Kerja & 0,949 & 0,049 & 19,253 & 0,000 \\
X3.3 <--- & Motivasi_Kerja & 0,993 & 0,042 & 23,655 & 0,000 \\
X3.4 <--- & Motivasi_Kerja & 0,924 & 0,045 & 20,512 & 0,000 \\
\hline
\end{tabular}

Sumber : Hasil olahan Peneliti dengan Amos Ver. 16.0

Tabel 2.

Nilai Loading Factor Variabel Eksogen

\begin{tabular}{llcc}
\hline \hline & & Konstrak & Factor Loading \\
\hline X1.1 & $<---$ & Budaya_Organisasi & 0,893 \\
X1.2 & $<---$ & Budaya_Organisasi & 0,855 \\
X1.3 & $<---$ & Budaya_Organisasi & 0,807 \\
X1.5 & $<---$ & Budaya_Organisasi & 0,758 \\
X1.6 & $<---$ & Budaya_Organisasi & 0,843 \\
X2.1 & $<---$ & Komitmen_Organisasi & 0,786 \\
X2.2 & $<---$ & Komitmen_Organisasi & 0,878 \\
X2.3 & $<---$ & Komitmen_Organisasi & 0,856 \\
X3.1 & $<---$ & Motivasi_Kerja & 0,931 \\
X3.2 & $<---$ & Motivasi_Kerja & 0,866 \\
X3.3 & $<---$ & Motivasi_Kerja & 0,932 \\
X3.4 & $<---$ & Motivasi_Kerja & 0,887 \\
\hline
\end{tabular}

Sumber : Hasil olahan Peneliti dengan Amos Ver. 16.0

Setelah dipastikan bahwa indikator yang digunakan merupakan penyusun variabel-variabel eksogen, maka langkah selanjutnya adalah mengetahui nilai factor loading dari masing-masing indikator dapat dilihat pada tabel 2 .

Dari Tabel 2 tersebut menunjukkan loading factor dari variabel budaya organisasi yang terendah adalah 0,758 pada indikator X1.5 sedangkan loading factor tertinggi adalah pada indikator $\mathrm{X} 1.1$ dengan nilai
0,893. Nilai loading factor tertinggi menunjukkan bahwa indikator tersebut merupakan konstrak pembentuk budaya organisasi yang paling baik.

Loading factor dari variabel komitmen organisasi yang terendah adalah 0,786 pada indikator X2.1 sedangkan loading factor tertinggi adalah pada indikator X2.2 dengan nilai 0,878 . Nilai loading factor tertinggi menunjukkan bahwa indikator tersebut merupakan konstrak pembentuk komitmen orga- 
nisasi yang paling baik.

Loading factor dari variabel motivasi kerja yang terendah adalah 0,866 pada indikator X3.2 sedangkan loading factor tertinggi adalah pada indikator X3.3 dengan nilai 0,932. Nilai loading factor tertinggi menunjukkan bahwa indikator tersebut merupakan konstrak pembentuk motivasi kerja yang paling baik.

\section{Confirmatory Factor Analisis Variabel Endogen}

Hasil uji CFA pada variabel endogen adalah sebagai berikut:

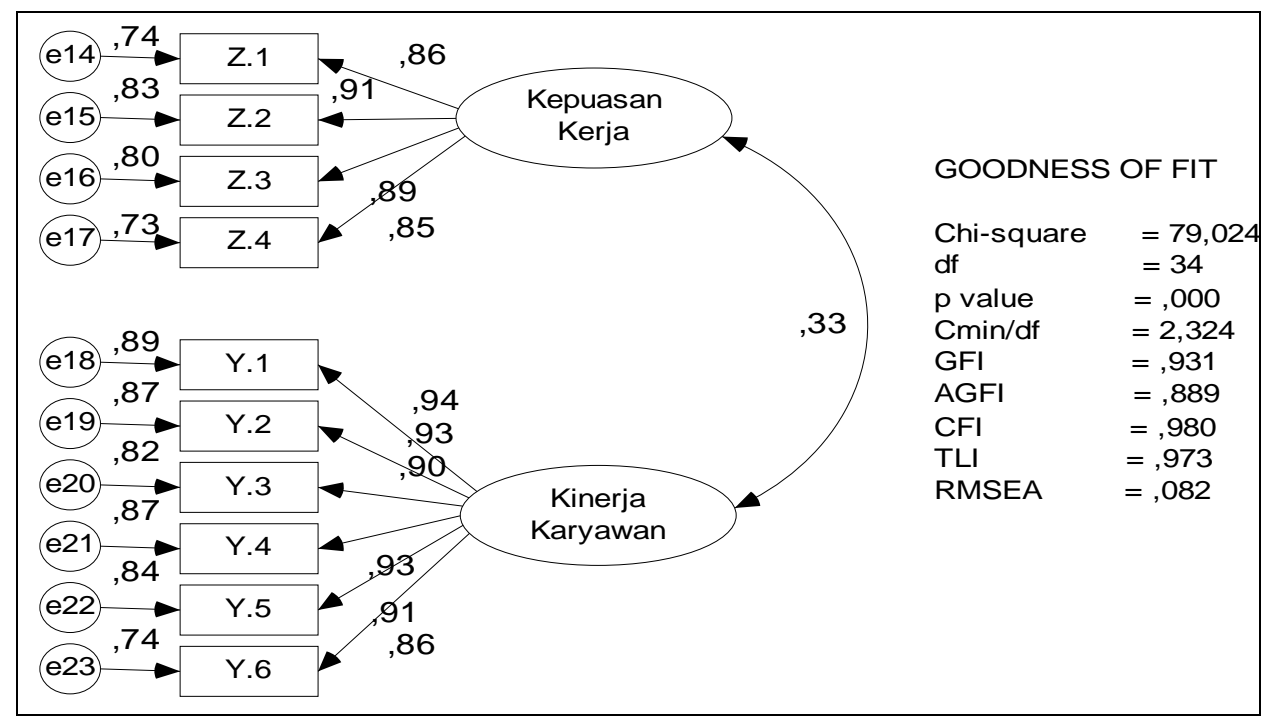

\section{Gambar 3}

Sumber : Hasil olahan Peneliti dengan Amos Ver. 16.0

Confirmatory Factor Analisis Variabel Endogen

Untuk memastikan indikator tersebut telah memenuhi syarat, dapat dilihat pada tabel 3 berikut :

Tabel 3.

Hasil Uji Validitas Kontrak Endogen

\begin{tabular}{lllcccc}
\hline \hline & & Konstrak & Estimate & S.E. & C.R. & P \\
\hline Z.1 & $<---$ & Kepuasan_Kerja & 1 & & & \\
$\mathbf{Z . 2}$ & $<---$ & Kepuasan_Kerja & 1,161 & 0,066 & 17,544 & 0,000 \\
$\mathbf{Z . 3}$ & $<---$ & Kepuasan_Kerja & 1,230 & 0,073 & 16,962 & 0,000 \\
$\mathbf{Z . 4}$ & $<---$ & Kepuasan_Kerja & 1,226 & 0,078 & 15,624 & 0,000 \\
$\mathbf{Y . 1}<---$ & Kinerja_Karyawan & 1 & & & \\
$\mathbf{Y . 2}$ & $<---$ & Kinerja_Karyawan & 0,944 & 0,036 & 26,409 & 0,000 \\
$\mathbf{Y . 3}$ & $<---$ & Kinerja_Karyawan & 0,904 & 0,039 & 23,360 & 0,000 \\
$\mathbf{Y . 4}$ & $<---$ & Kinerja_Karyawan & 0,964 & 0,037 & 26,350 & 0,000 \\
$\mathbf{Y . 5}$ & $<---$ & Kinerja_Karyawan & 0,907 & 0,037 & 24,346 & 0,000 \\
$\mathbf{Y . 6}$ & $<---$ & Kinerja_Karyawan & 0,906 & 0,045 & 19,984 & 0,000 \\
\hline
\end{tabular}

Sumber : Hasil olahan Peneliti dengan Amos Ver. 16.0

Setelah dipastikan bahwa indikator di atas merupakan konstrak penyusun variabel kepuasan kerja dan kinerja karyawan, maka langkah selanjutnya adalah menge tahui nilai loading factor dari masing-masing indikator variabel kepuasan kerja dan kinerja karyawan. 
Tabel 4.

Nilai Loading Factor Variabel Endogen

\begin{tabular}{cccc}
\hline \hline & & Konstrak & Factor Loading \\
\hline Z.1 & $<---$ & Kepuasan_Kerja & 0,860 \\
Z.2 & $<---$ & Kepuasan_Kerja & 0,910 \\
Z.3 & $<---$ & Kepuasan_Kerja & 0,893 \\
Z.4 & $<---$ & Kepuasan_Kerja & 0,853 \\
Y.1 & $<---$ & Kinerja_Karyawan & 0,945 \\
Y.2 & $<---$ & Kinerja_Karyawan & 0,933 \\
Y.3 & $<---$ & Kinerja_Karyawan & 0,903 \\
Y.4 & $<---$ & Kinerja_Karyawan & 0,933 \\
Y.5 & $<---$ & Kinerja_Karyawan & 0,914 \\
Y.6 & $<---$ & Kinerja_Karyawan & 0,859 \\
\hline
\end{tabular}

Sumber : Hasil olahan Peneliti dengan Amos Ver. 16.0

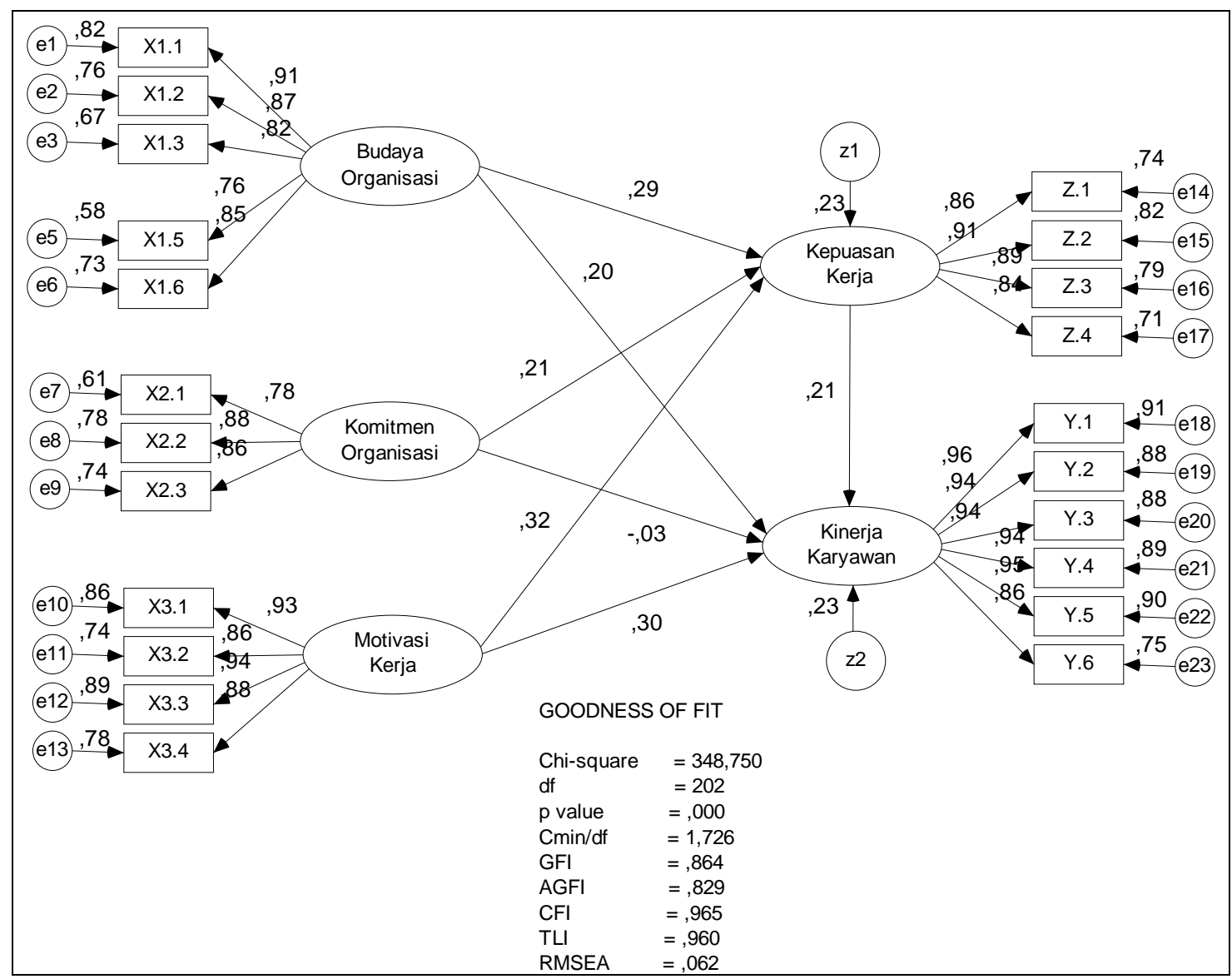

Gambar 4

Sumber : Hasil olahan Peneliti dengan Amos Ver. 16.0

Struktural Model Penelitian

Pada tabel 4 di atas menunjukkan loading factor dari variabel kepuasan kerja yang terendah adalah 0,853 pada indikator Z.4 sedangkan loading factor tertinggi adalah pada indikator Z.2 dengan nilai 0,910. Nilai loading factor tertinggi menunjukkan bahwa indikator tersebut merupakan konstrak pem bentuk kepuasan kerja paling baik. 
Loading factor dari variabel kinerja karyawan yang terendah adalah 0,859 pada indikator Y.6 sedangkan loading factor tertinggi adalah pada indikator Y.1 dengan nilai 0,945 . Nilai loading factor tertinggi menunjukkan bahwa indikator tersebut merupakan konstrak pembentuk kinerja karyawan paling baik.

\section{Analisis Structural Equation Modeling} (SEM)

Hasil analisis estimasi model struktural setelah dimodifikasi dapat disajikan pada gambar 4 .

Hasil perhitungan nilai indeks-indeks goodness of fit yang dihasilkan model struktural setelah dimodifikasi adalah seperti pada tabel 5 .

Hasil perhitungan menunjukkan kriteria kesesuaian model sudah memberikan indeks yang cukup sesuai dari yang direkomendasi.

\section{Hasil Uji Kausalitas Regression Weight}

Hasil uji kausalitas regression weight untuk mengetahui pengaruh dari masingmasing variabel dapat disajikan pada tabel 6.

Tabel 5.

Nilai Goodness of Fit dan Cutt off Value Modification Model

\begin{tabular}{cccc}
\hline \hline Kriteria & Hasil Uji Model & Nilai Kritis & Keterangan \\
\hline Prob. X' Chi square & 0,000 & $\geq 0,05$ & Tidak Fit Model \\
Cmin/DF & 1,726 & $\leq 2,00$ & Fit Model \\
RMSEA & 0,062 & $\leq 0,08$ & Fit Model \\
GFI & 0,864 & $\geq 0,90$ & Tidak Fit Model \\
AGFI & 0,829 & $\geq 0,90$ & Tidak Fit Model \\
TLI & 0,960 & $\geq 0,90$ & Fit Model \\
CFI & 0,965 & $\geq 0,90$ & Fit Model \\
\hline
\end{tabular}

Sumber : Hasil olahan Peneliti dengan Amos Ver. 16.0

Tabel 6.

Uji Kausalitas Regression Weight

\begin{tabular}{|c|c|c|c|c|c|c|c|}
\hline & Path & & $\begin{array}{c}\text { Unstandardized } \\
\text { Estimate }\end{array}$ & $\begin{array}{l}\text { Standardized } \\
\text { Estimate }\end{array}$ & $\begin{array}{c}\text { Standart } \\
\text { Error } \\
\text { (S.E.) }\end{array}$ & $\begin{array}{l}\text { Critical } \\
\text { Ratio } \\
\text { (C.R.) }\end{array}$ & $\begin{array}{c}\text { P-value } \\
(\mathrm{P})\end{array}$ \\
\hline $\begin{array}{l}\text { Budaya } \\
\text { Organisasi }\end{array}$ & $\rightarrow$ & $\begin{array}{l}\text { Kepuasan } \\
\text { Kerja }\end{array}$ & 0,262 & 0,287 & 0,065 & 4,032 & 0,000 \\
\hline $\begin{array}{l}\text { Komitmen } \\
\text { Organisasi }\end{array}$ & $\rightarrow$ & $\begin{array}{l}\text { Kepuasan } \\
\text { Kerja }\end{array}$ & 0,191 & 0,209 & 0,067 & 2,860 & 0,004 \\
\hline Motivasi Kerja & $\rightarrow$ & $\begin{array}{l}\text { Kepuasan } \\
\text { Kerja }\end{array}$ & 0,296 & 0,322 & 0,065 & 4,545 & 0,000 \\
\hline $\begin{array}{l}\text { Budaya } \\
\text { Organisasi }\end{array}$ & $\rightarrow$ & $\begin{array}{l}\text { Kinerja } \\
\text { Karyawan }\end{array}$ & 0,247 & 0,198 & 0,090 & 2,747 & 0,006 \\
\hline $\begin{array}{l}\text { Komitmen } \\
\text { Organisasi }\end{array}$ & $\rightarrow$ & $\begin{array}{l}\text { Kinerja } \\
\text { Karyawan }\end{array}$ & $-0,039$ & $-0,031$ & 0,090 & $-0,437$ & 0,662 \\
\hline Motivasi Kerja & $\rightarrow$ & $\begin{array}{l}\text { Kinerja } \\
\text { Karyawan }\end{array}$ & 0,374 & 0,295 & 0,092 & 4,083 & 0,000 \\
\hline Kepuasan Kerja & $\rightarrow$ & $\begin{array}{l}\text { Kinerja } \\
\text { Karyawan }\end{array}$ & 0,285 & 0,208 & 0,108 & 2,635 & 0,008 \\
\hline
\end{tabular}


Berdasarkan Tabel di atas, dapat dijelaskan sebagai berikut:

1. Hipotesis 1: Budaya organisasi berpengaruh signifikan terhadap kepuasan kerja. Hasil estimasi parameter variabel budaya organisasi terhadap kepuasan kerja berdasarkan indikator-indikatornya menunjukkan hasil yang signifikan dengan nilai $C R$ 4,032. Nilai ini lebih besar dari 1,96. Disamping itu diperoleh taraf signifikansi 0,000 ( $p<0,05)$. Sehingga hipotesis pertama budaya organisasi berpengaruh signfikan terhadap kepuasan kerja diterima kebenarannya.

2. Hipotesis 2: Komitmen organisasi berpengaruh signifikan terhadap kepuasan kerja. Hasil estimasi parameter variabel komitmen organisasi terhadap kepuasan kerja berdasarkan indikator-indikatornya menunjukkan hasil yang signifikan dengan nilai $C R$ 2,860. Nilai ini lebih besar dari 1,96. Disamping itu diperoleh taraf signifikansi 0,004 ( $p<0,05)$. Sehingga hipotesis kedua komitmen organisasi berpengaruh signfikan terhadap kepuasan kerja diterima kebenarannya.

3. Hipotesis 3: Motivasi kerja berpengaruh signifikan terhadap kepuasan kerja. Hasil estimasi parameter variabel motivasi kerja terhadap kepuasan kerja berdasarkan indikator-indikatornya menunjukkan hasil yang signifikan dengan nilai CR 4,545. Nilai ini lebih besar dari 1,96. Disamping itu diperoleh taraf signifikansi $0,000 \quad(p<0,05)$. Sehingga hipotesis ketiga motivasi kerja berpengaruh signfikan terhadap kepuasan kerja diterima kebenarannya.

4. Hipotesis 4: Budaya organisasi berpengaruh signifikan terhadap kinerja karyawan. Hasil estimasi parameter variabel budaya organisasi terhadap kinerja karyawan berdasarkan indikator - indikatornya menunjukkan hasil yang signifikan dengan nilai $C R \quad 2,747$. Nilai ini lebih besar dari 1,96. Disamping itu diperoleh taraf signifikansi $0,006(\mathrm{p}<$ $0,05)$. Sehingga hipotesis keempat budaya organisasi berpengaruh signfikan terhadap kinerja karyawan diterima kebenarannya.

5. Hipotesis 5: Komitmen organisasi berpengaruh signifikan terhadap kinerja karyawan. Hasil estimasi parameter variabel komitmen organisasi terhadap kinerja karyawan berdasarkan indikator - indikatornya menunjukkan hasil yang tidak signifikan dengan nilai $C R-0,437$. Nilai ini lebih kecil dari 1,96. Disamping itu diperoleh taraf signifikansi 0,662 $(p>0,05)$. Sehingga hipotesis kelima komitmen organisasi berpengaruh signifikan terhadap kinerja karyawan tidak dapat diterima kebenarannya.

6. Hipotesis 6: Motivasi kerja berpengaruh signifikan terhadap kinerja karyawan. Hasil estimasi parameter variabel motivasi kerja terhadap kinerja karyawan berdasarkan indikator-indikatornya menunjukkan hasil yang signifikan dengan nilai $C R$ 4,083. Nilai ini lebih besar dari 1,96. Disamping itu diperoleh taraf signifikansi $0,000 \quad(p<0,05)$. Sehingga hipotesis keenam motivasi kerja berpengaruh signfikan terhadap kinerja karyawan diterima kebenarannya.

7. Hipotesis 7: Kepuasan kerja berpengaruh signifikan terhadap kinerja karyawan. Hasil estimasi parameter variabel kepuasan kerja terhadap kinerja karyawan berdasarkan indikator-indikatornya menunjukkan hasil yang signifikan dengan nilai $C R \quad 2,635$. Nilai ini lebih besar dari 1,96. Disamping itu di peroleh taraf signifikansi $0,008(\mathrm{p}<0,05)$. Sehingga hipotesis ketujuh kepuasan kerja berpengaruh signfikan terhadap kinerja karyawan diterima kebenarannya. 
Tabel 7.

Rangkuman Uji Hipotesis

\begin{tabular}{lllc}
\hline & \multicolumn{1}{c}{ Hipotesis } & P value & $\begin{array}{c}\text { Hasil } \\
\text { Analisis }\end{array}$ \\
\hline $\mathrm{H}_{1}$ & $\begin{array}{l}\text { Budaya organisasi berpengaruh signifikan } \\
\text { terhadap kepuasan kerja }\end{array}$ & 0,000 & Diterima \\
$\mathrm{H}_{2}$ & $\begin{array}{l}\text { Komitmen organisasi berpengaruh signifikan } \\
\text { terhadap kepuasan kerja }\end{array}$ & 0,004 & Diterima \\
$\mathrm{H}_{3} \quad \begin{array}{l}\text { Motivasi kerja berpengaruh signifikan terhadap } \\
\text { kepuasan kerja }\end{array}$ & 0,000 & Diterima \\
$\mathrm{H}_{4} \quad \begin{array}{l}\text { Budaya organisasi berpengaruh signifikan } \\
\text { terhadap kinerja karyawan }\end{array}$ & 0,006 & Diterima \\
$\mathrm{H}_{5} \quad \begin{array}{l}\text { Komitmen organisasi berpengaruh signifikan } \\
\text { terhadap kinerja karyawan }\end{array}$ & 0,662 & Ditolak \\
$\mathrm{H}_{6} \quad \begin{array}{l}\text { Motivasi kerja berpengaruh signifikan terhadap } \\
\text { kinerja karyawan }\end{array}$ & 0,000 & Diterima \\
$\mathrm{H}_{7} \quad \begin{array}{l}\text { Kepuasan kerja berpengaruh signifikan terhadap } \\
\text { kinerja karyawan }\end{array}$ & 0,008 & Diterima \\
\hline
\end{tabular}

Sumber : Hasil olahan Peneliti dengan Amos Ver. 16.0

\section{SIMPULAN DAN SARAN Simpulan}

Berdasarkan hasil analisis data dengan menggunakan Structural Equation Modeling (SEM) melalui program AMOS versi 16.0 dan pembahasan hasil penelitian yang telah dikemukakan pada pembahasan sebelumnya, maka dapat disimpulkan beberapa hal penting dalam penelitian ini sebagai berikut:

1. Budaya organisasi berpengaruh positif dan signifikan terhadap kepuasan kerja karyawan PT Indofood Sukses Makmur Tbk di Kalimantan dengan nilai koefisien 0,287 dan p-value 0,000.

2. Komitmen organisasi berpengaruh positif dan signifikan terhadap kepuasan kerja karyawan PT. Indofood Sukses Makmur Tbk di Kalimantan dengan nilai koefisien 0,209 dan p-value 0,004.

3. Motivasi kerja berpengaruh positif dan signifikan terhadap kepuasan kerja karyawan PT Indofood Sukses Makmur Tbk di Kalimantan dengan nilai koefisien 0,322 dan p-value 0,000.

4. Budaya organisasi berpengaruh positif dan signifikan terhadap kinerja karyawan PT Indofood Sukses Makmur Tbk di Kalimantan dengan nilai koefisien 0,198 dan p-value 0,006.

5. Komitmen organisasi tidak berpengaruh atau berpengaruh tidak signifikan terhadap kinerja karyawan PT. Indofood Sukses Makmur Tbk di Kalimantan dengan nilai koefisien -0,031 dan p-value 0,662 .

6. Motivasi kerja berpengaruh positif dan signifikan terhadap kinerja karyawan PT. Indofood Sukses Makmur Tbk di Kalimantan dengan nilai koefisien 0,295 dan p-value 0,000.

7. Kepuasan kerja berpengaruh positif dan signifikan terhadap kinerja karyawan PT Indofood Sukses Makmur Tbk di Kalimantan dengan nilai koefisien 0,208 dan p-value 0,008.

\section{Saran}

Dari hasil penelitian ada beberapa saran yang disampaikan yaitu:

1. Budaya organisasi berdampak signifikan terhadap kepuasan dan kinerja karyawan. PT Indofood Sukses Makmur. Tbk diharapkan mampu menciptakan budaya organisasi yang memberi kan kenyamanan bagi setiap karyawan, 
sehingga memberikan keleluasaan kepada karyawan untuk beraktivitas yang mendukung tujuan perusahaan. Apabila hal ini terjadi, maka akan terjadi peningkatan kepuasan kerja yang pada akhirnya akan meningkatkan kinerja karyawan.

2. Komitmen organisasi berdampak signifikan terhadap kepuasan karyawan, dan tidak berdampak langsung terhadap kinerja. Salah satu penyebabnya adalah adanya kebijakan untuk meniadakan uang lembur. Hal yang bisa dilakukan oleh PT Indofood Sukses Makmur. Tbk adalah mempertimbangkan kebijaksanaan dalam pemberian uang lembur sebagai komponen kompensasi variabel, hal ini untuk meningkatkan kinerja karyawan melalui komitmen organisasi.

\section{DAFTAR PUSTAKA}

Arikunto, S. 2006. Prosedur Pene- litian: Suatu Pendekatan Praktik, Edisi Revisi VI, Penerbit PT. Rineka Cipta, Jakarta.

Djati, S. P. 2003. Kajian Terhadap Kepuasan Kompensasi, Komitmen Organisasi dan Prestasi Kerja, Jurnal Management UK Petra, Surabaya.

Edwardin, L. T. A. S. 2006. Analisis Pengaruh Kompetensi Komunikasi, Kecerdasan Emosional, dan Budaya Organisasi terhadap Kinerja Karyawan (Studi Pada PT Pos Indonesia (Persero) Se Kota Semarang), Universitas Diponegoro.

Ferdinand, A. 2002. Structural Equation Model Dalam Penelitian Manajemen: Dasar-dasar permodelan. Edisi Indonesia. Jakarta: FJex Media Komputindo Kelompok Gramedia.
Gibson, James L. John, M. Ivancevich dan James H. Donnaly. 2006. Organisasi, Perilaku, Struktur dan Proses. Edisi 8, Terjemahan Bina Rupa Aksara, Jakarta.

Gitosudarmo, I. dan I Nyoman Sudita, 2002, Perilaku Keorganisasian, Edisi Pertama, BPFE, Yogyakarta.

Kluvers, R. and T, John. 2009. The Effect On Motivation of A Change in Rewards. International Review of Business Research Papers 5(5): 147-159.

Koesmono, H. T. 2005. Pengaruh Budaya Organisasi terhadap Motivasi dan Kepuasan kerja serta kinerja karyawan pada sub Sektor Industri pengolahan Kayu Skala menengah di Jawa Timur.

Kreitner, R. and K. Angelo. 2003. Perilaku Organisasi, Buku I, Salemba Empat, Jakarta.

Luthans, F. 2005. Perilaku Organisasi, Edisi 10, Andi, Yogyakarta.

Mangkunegara, A. A. Anwar Prabu, 2006, Evaluasi Kinerja SDM, Penerbit Refika Aditama, Bandung.

Robbins P. S. 2003. Perilaku Organisasi Jilid 1, PT. Indeks Kelompok Gramedia, Jakarta.

Robbins, S. P., and J, Timothy A., 2008, Perilaku Organisasi, Buku 1, Edisi 12, Salemba Empat, Jakarta.

Toha, M. 1993. Perilaku Organisasi, Rajawali Press, Jakarta.

Wexley, N. K. dan Y. A. Gary. 1992. Perilaku Organisasi dan Psikologi Personalia, Rineka Cipta, Jakarta. 